\title{
RESEARCH OF RENEWABLE ENERGY SOURCES BASED ON WIND IN AREA OF HERZEGOVINA
}

\author{
Božo Goluža, Ivana Matijević
}
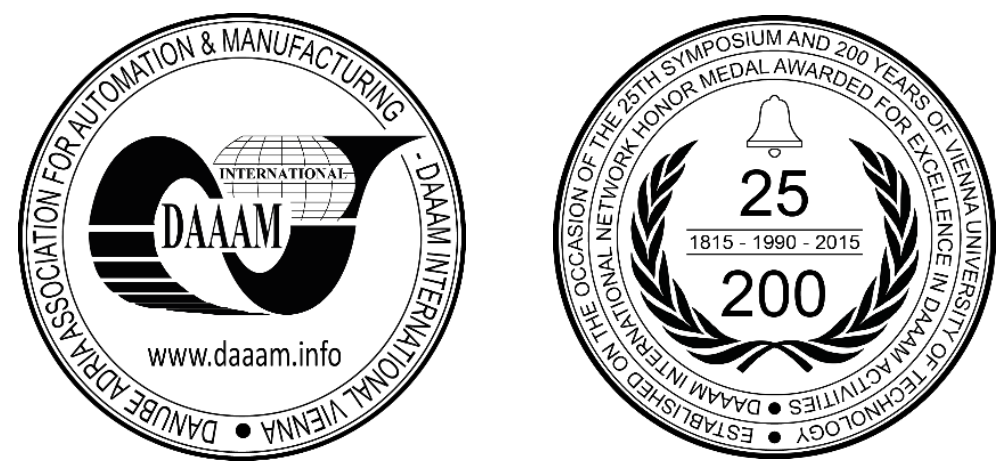

This Publication has to be referred as: Goluza, B[ozo] \& Matijevic, I[vana] (2016). Research of Renewable Energy Sources Based on Wind in Area of Herzegovina, Proceedings of the 27th DAAAM International Symposium, pp.08040810, B. Katalinic (Ed.), Published by DAAAM International, ISBN 978-3-902734-08-2, ISSN 1726-9679, Vienna, Austria

DOI: $10.2507 / 27$ th.daaam.proceedings.116

\begin{abstract}
Modern ways of developing product and techniques in its production are based on maximum optimization. To ensure this it is inevitable for function of development in company to be based on principles of innovation activities in technical and modern principles of organizing of company in every segment of its activity. On the example of researching meteorological characteristics in Herzegovina the model of optimization in phase of researching and designing of development of energy facilities based on wind energy is presented. For this part of paper, I used results of domestic companies' researches which adjusted this process to EU standards so investment process can be adjusted to criteria of European Investment Bank.
\end{abstract}

Keywords: renewable energy sources; wind energy; optimization; research and design

\section{Introduction}

Characteristics of Dinara system in climatological assessment when it comes to wind are classified into complex conditions and are similar as parts of the area in Ireland, Spain and the mountains of Austria. Based on research of characteristics of the wind on the mountain Čabulja slopes (Velika Vlajna) the methodology of necessary information research is shown so the investment process in the sector of wind energy could be realized. The meteorological station in the city of Mostar has a database on the characteristics of the wind back to the period of Austro-Hungary. In the period from 1956 it started with modern methods of measuring weather conditions where in the graphs are displayed in segments of hour defined meteorological condition of wind. [1] Appropriate methods of modelling respecting graphic forms in the period 2006-2011 through the project FP6 were obtained results on the characteristics of the wind every 10 minutes by which is a database for projects of wind power plants extended for a period of 55 years. [2] These databases through statistical analysis provide extremely high-quality results in forecasting of meteorological characteristics that there is not one country in the EU, which increases the interest of future investors because the risks of the investments with the technical aspects are minimized. 


\section{Selection of micro location for measuring station installation}

Location Velika Vlajna is considered as a place for energy use of wind resource for analysis of the possibility of using wind energy in the region of Western Herzegovina.

In the analysis of the use of wind the first step for the production of electricity is the selection of locations for measuring poles and their installation, which is done by the following criteria:

- Wind Resources

- Topography

- Geology and Seismology

- Access to electricity grid

- Access roads

- Freezing

- Lightning

- The vegetation and other obstacles

- Legislation of the environment protection

- Private ownership

- High quality signal of GSM network [3]

Terrain of Velika belong to the extreme south-eastern part of the mountain Čabulja. Location Velika Vlajna (Jastrebinka) is located north-west of Mostar. The topography is suitable for the development of wind power station because of mild slope and any obstacles. On location Velika Vlajna are installed $10 \mathrm{~m}$ and $50 \mathrm{~m}$ high measuring stations.

Selected point $(6477498,4805321)$ for 10 -meter pole at a height of 1050 meters due to favourable topography, flat lofty slope, and wide flat parts at the top and free access has good conditions for the development of wind farms. It is well exposed to all wind directions. It is possible to access by car.

Selected point $(6478089,4805625)$ for 50 -meter pole is near a communication pole. It is well exposed to all wind directions. Communication pole has no effect on measurement due to braced structures and sufficient distance from measuring pole (approximately $200 \mathrm{~m}$ ). On this monitoring station are set two levels of measurements of wind: $30 \mathrm{~m}$ and $50 \mathrm{~m}$.

\section{Review and analysis of wind potential data}

The following graph shows the availability of data and the mean wind in months. The red line shows the mean wind speed for a one-year period 11/01/2004 to 10/31/2005 (7.22 m / s). This period was chosen because of its high data availability $(96.98 \%)$.

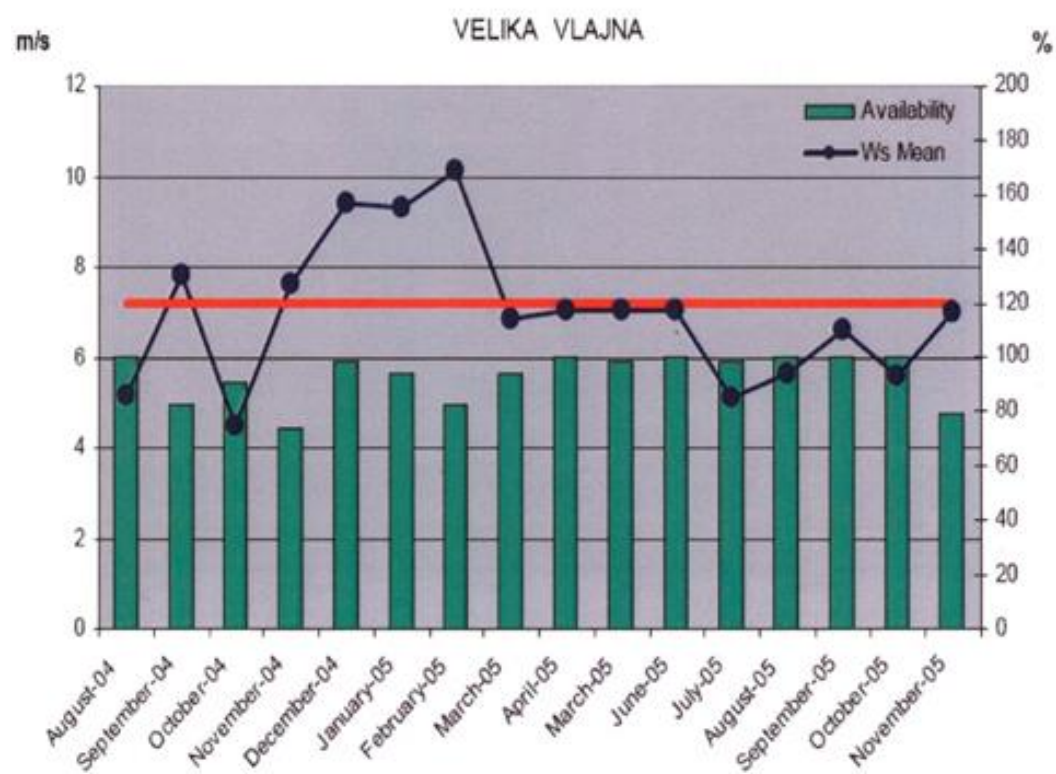

Fig. 1. Diagram of average wind speed and availability of data on the measuring station Velika Vlajna 10m [4] 


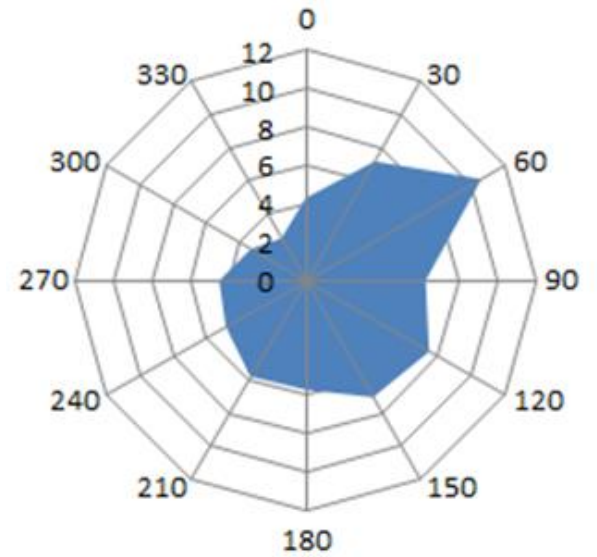

Fig. 2. Wind speed rose [4]

Wind rose describes wind speeds from 12 different directions, and it looks like a compass. Each of the 12 courses includes $30^{\circ}$ horizon as the standard for the European Wind Atlas. The characteristics of the wind at the location can vary from year to year to $10 \%$, so it is recommended to take measurements for more years as it is worked in this study.

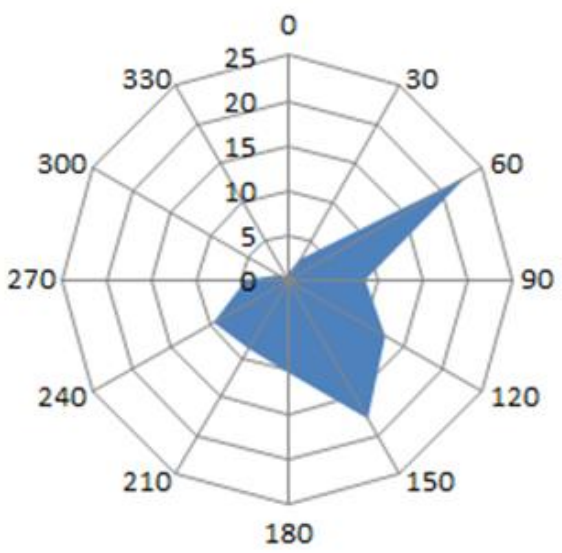

Fig. 3. Frequency rose [4]

\begin{tabular}{|l|l|l|l|}
\hline \multirow{2}{*}{ Temperature $\left({ }^{\circ} \mathbf{C}\right)$} & Min & Mean & Max \\
\cline { 2 - 4 } & $-15,2$ & 11,1 & 33,4 \\
\hline \multirow{2}{*}{ Speed (m/s) } & Min & Mean & Max \\
\hline & 0,4 & 7,2 & 42,8 \\
\hline Dominant wind direction & NNI & \\
\hline Frost days (\%/god) & 0,5 & \\
\hline Days of quite (\%/god) & 17,17 \\
\hline Turbulence intensity (\%) & 11,1 & \\
\hline Air density $\left(\mathbf{k g} / \mathbf{m}^{\mathbf{3}}\right)$ & 1,098 & \\
\hline
\end{tabular}

Table 1. Meteorological data [4]

Dominant wind direction is north-northeast. Based on these results it was decided to install 50-meter pole. After installing the 50-meter pole it went to test wind speed and direction at both locations, and within three years the data for the wind were obtained:

- $10 \mathrm{~m}$ measuring stations data are available from 07.19.2004. to 10.13.2007. (8 days unrecorded data). After threeyear measuring wind speed is an average of $7.1 \mathrm{~m} / \mathrm{s}$

- $\quad 50 \mathrm{~m}$ measuring stations data are available from 07.14.2005. to 01.23.2007. (large lack of data from 12.06.2005. to 01.07.2006). With this lack there is no larger measuring defects. If we examine the correspondence of wind courses of measuring stations $10 \mathrm{~m}$ and $50 \mathrm{~m}$, according to Figure 4 can be concluded that they are not linear. Due to the different orography and distance of station there is a difference in signal. 


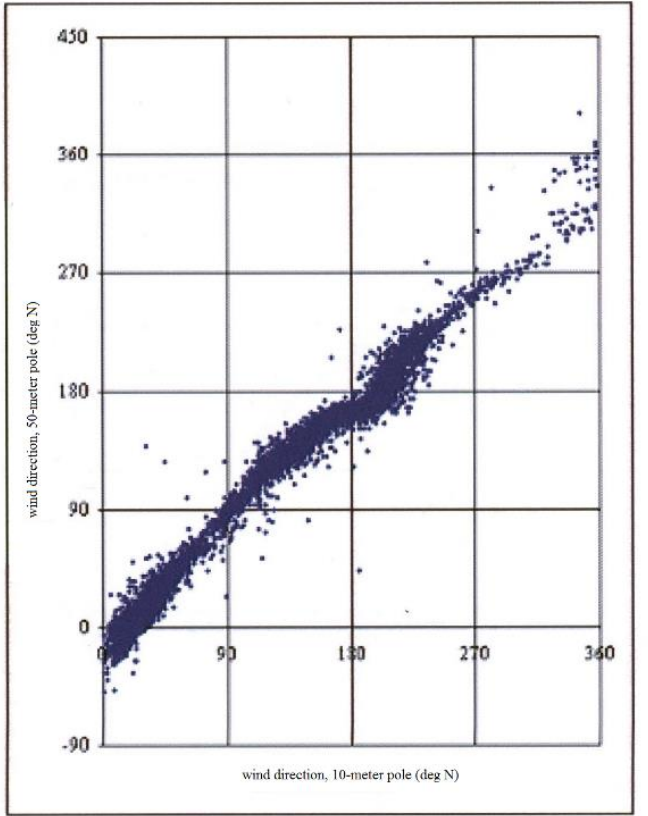

Fig. 4. Comparison of wind directions with both measuring stations [4]

Therefore, it is approached to the polynomial approximation and gets the following picture:

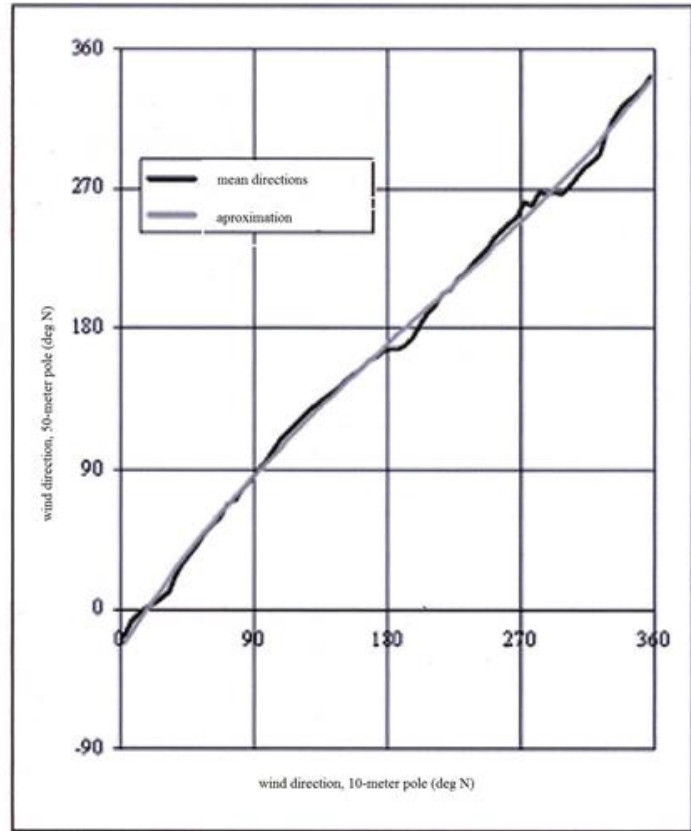

Fig. 5. The relationship between the wind direction signal and their approximation [4]

In this way are filled the deficiencies of data with $50 \mathrm{~m}$ pole. Gradient of wind speed varies moderately, but during the day obviously. From diagram it is evident that the influence of orography and roughness of the terrain on the wind directions at the measuring station is minimal. The relatively small oscillations indicate that there is a slightly variety in the angle of action for different wind speeds (north, south). Figure 6 shows average wind speeds during the day.

From the diagram it is evident that the winter winds (wind) energy-efficient (the wind speed). High intensity is more pronounced at night because of the greater temperature difference between Herzegovina - Bosnia (winter) and Herzegovina - Adriatic Sea (in summer). The following figure shows the daily turbulence intensity.

Turbulence in the day shows the influence of thermal effects caused by radiation, which is significantly more expressed during the day than at night.

Small wind speeds have high turbulence intensity and significantly affect the overall turbulence. The following illustration shows the overall turbulence intensity as a function of the wind direction. 


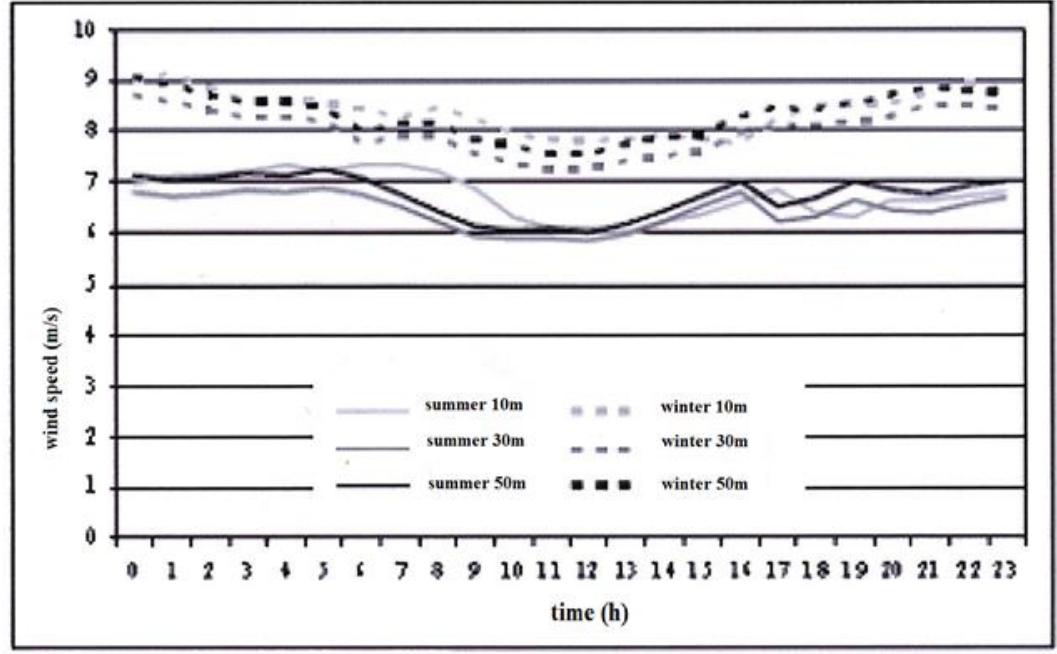

Fig. 6. Daily average wind speed [4]

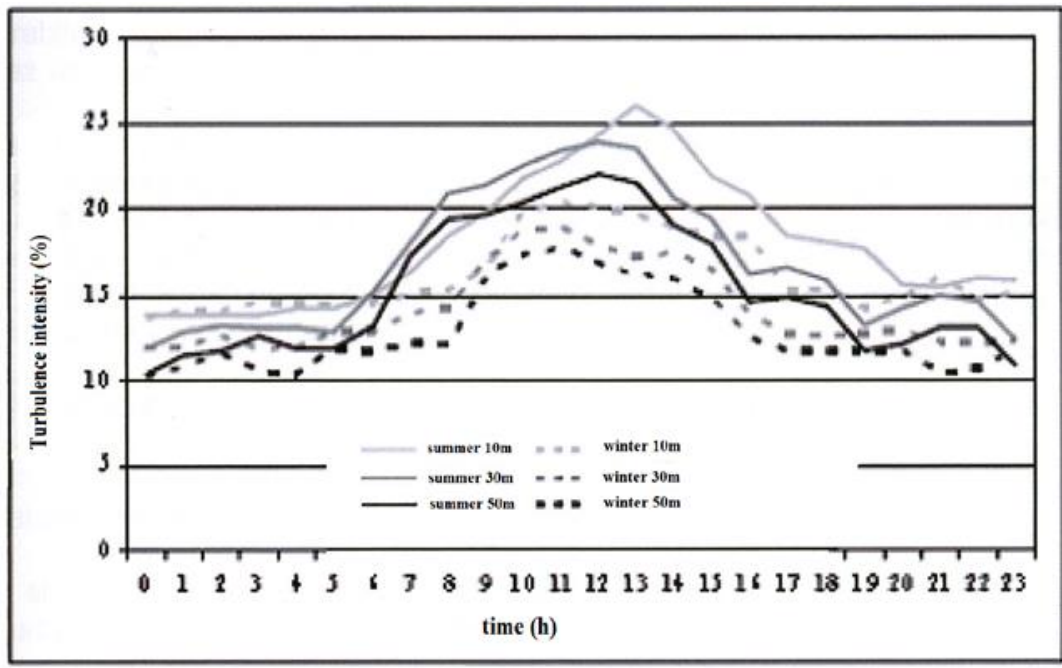

Fig. 7. Daily mean intensity of turbulence [4]

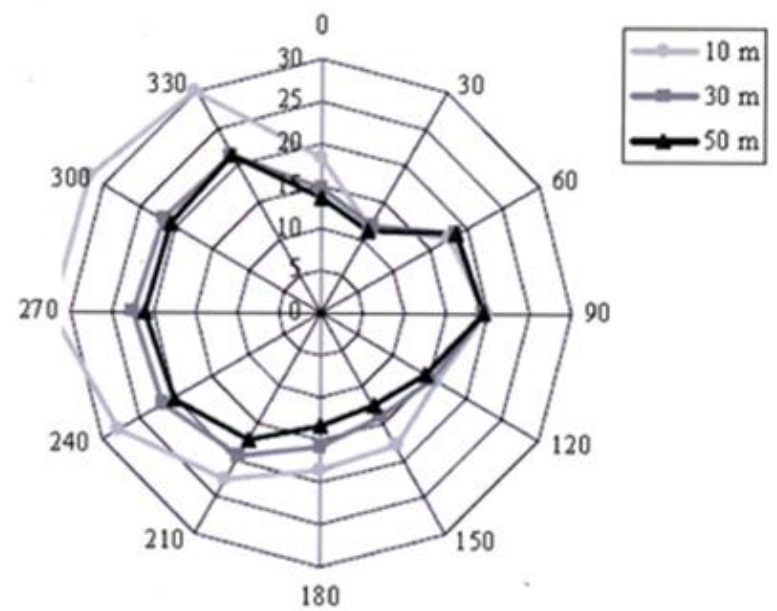

Fig. 8. Mean intensity of turbulence in percentage as a function of wind direction for all wind speeds [4]

In the part from $0^{\circ}$ to $90^{\circ}$ turbulence on both measuring poles are almost identical except for the north of $10 \mathrm{~m}$ measuring station, where it is visible the impact of a pinwheel that increases its turbulence in this sector. The fact that the level of turbulence between the measuring stations in this direction are comparable means that wind follows the surface of the ground and reaches the 10-meter pole from below the top without major disturbances. 
On the other side, great turbulence on the $10 \mathrm{~m}$ measuring station on the southern side over the southwest to the northwest indicate the possible impact of higher roughness in that direction. There is a bigger number of shrubs and trees that obviously have an impact. It is noted that turbulence is significantly lower at higher altitudes above the earth in this direction. However, the influence of the smaller top to the northwest side causes moderately increased turbulence at higher altitudes also.

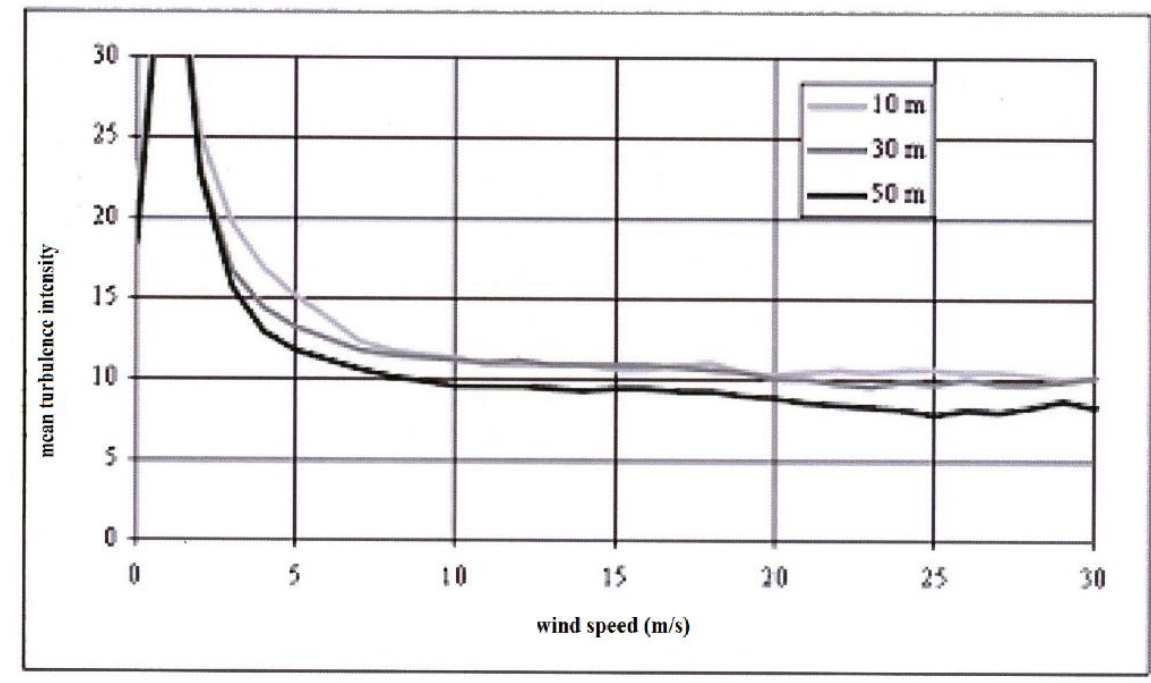

Fig. 9. Mean turbulence intensity as a function of wind speed [4]

Little impact of anemometer mounting at a height of $30 \mathrm{~m}$ can be recognized on the part of the $180^{\circ}$ to $210^{\circ}$. It is assumed that at the part of $90^{\circ}$ is there the impact of a telecommunication pole. According to Figure 8., wind speed relevant to the operation of wind turbines causes pretty low turbulence, which meets the requirements for the selection of the turbine class II.

Figures 10 and 11 show the importance of the dominant direction:

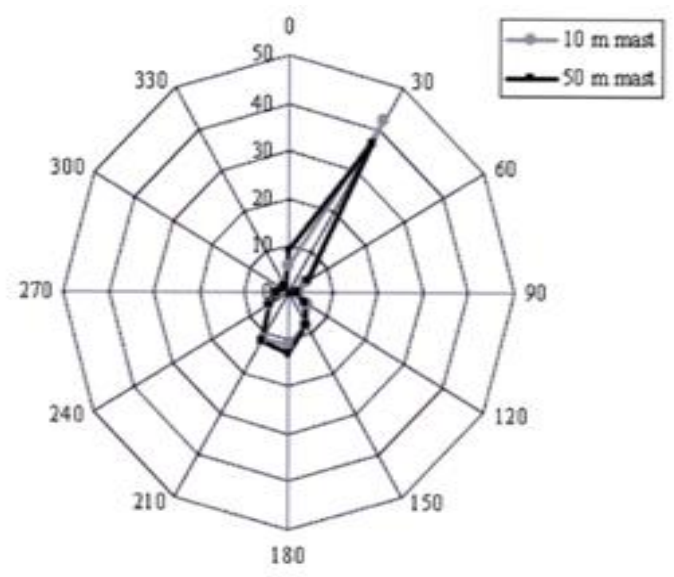

Fig. 10. A three-year wind frequency at both measuring stations (\%) [4]

Figure 11 shows a lower wind speed in the north due to the position of a pinwheel. If you take into account Figure 10 this difference has no significance. The mean wind speed at height of $30 \mathrm{~m}$ is $30^{\circ}$, and also at $60^{\circ}$ and $90^{\circ}$ is similar on both measurement station which is explained by the influence of turbulence as already. If it takes exception effect from one pole to the other difference in the mean wind speed at a height of $30 \mathrm{~m}$ and $50 \mathrm{~m}$ is $0.28 \mathrm{~m} / \mathrm{s}$. The uncertainty caused by measuring poles wind speed at $10 \mathrm{~m}$ and $50 \mathrm{~m}$ pole, difference in the mean wind speed is around $0.1-0.2 \mathrm{~m} / \mathrm{s}$ at the top of the $50 \mathrm{~m}$ pole.

This paper clearly shows that the dominant wind direction is NNE and NE. Turbulence in the day shows the influence of thermal effects caused by radiation, which is significantly more expressed during the day than at night.

For extrapolation purposes of wind data from wind station, for the long term have been used wind speeds and directions from weather stations Mostar, Šibenik, Split-Marjan, Split-Resnik and Dubrovnik-airport. By all the data has been verified stability and errors. Some individual data is discarded. 


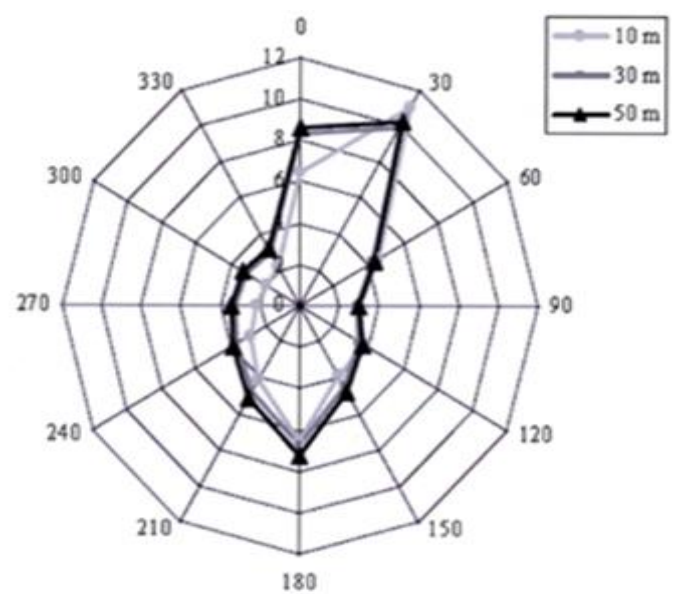

Fig. 11. Average wind speed in 3 years $(\mathrm{m} / \mathrm{s})$ [4]

By the extrapolation of wind data on a long-term period it seemed that the first 5 years of data available with a frequency of 6 hours and a midnight data partially missing. It was also found several deficiencies in the data in all sets. Recent data have partly hour resolution also. A number of data are often lacking, and sometimes at night and during the temperature below $0{ }^{\circ} \mathrm{C}$.

\section{Conclusion}

The aim of this paper was to represent a results of wind energy research at mountain of Čabulja (Velika Vlajna). This paper clearly shows that the dominant wind direction is NNE and NE. Turbulence in the day shows the influence of thermal effects caused by radiation, which is significantly more expressed during the day than at night.

For extrapolation purposes of wind data from wind station, for the long term have been used wind speeds and directions from weather stations Mostar, Šibenik, Split-Marjan, Split-Resnik and Dubrovnik-airport. By all the data has been verified stability and errors. Some individual data is discarded.

By the extrapolation of wind data on a long-term period it seemed that the first 5 years of data available with a frequency of 6 hours and a midnight data partially missing. It was also found several deficiencies in the data in all sets. Recent data have partly hour resolution also. A number of data are often lacking, and sometimes at night and during the temperature below $0{ }^{\circ} \mathrm{C}$.

The conclusion is that there is a huge potential for building wind farm on Velika Vlajna. The next step would be installation of wind farm, which is in the procedure. After installation the results would be constantly recorded, analysed and compared with research results.

\section{References}

[1] Zlomušica, E.; Behmen, M.; Ćatović, F.; Maričić, Đ. (2004). Perspektive BiH u instaliranju vjetroenergetskih kapaciteta, 3. Skup Industrijska energetika 2004. u organizaciji Društva tehničara SiCG, 2004, Donji Milanovac

[2] Behmen, M.; Zlomušica, E. (2008). Renevable energy sources- wind energy in BiH, The Network of Academies of Sciences in OIC Countries Nasic, 2008, Kazan, Tatarstan

[3] Behmen, M.; Čampara, M.; Zlomušica, E.; Samardžić, Ž; Domljan, V. (2009). The risks of building wind farms in Bosnia and Herzegovina, International economic conference, 2009, Tuzla

[4] Matijevic, I. et al. Contribution to the study of wind energy in complex terrain in the case of wind farms Velika Vlajna, Mostar, 2009

[5] Behmen, M.; Zlomušica, E.; Dedić, R.; Manjgo, M.; Badžak, I., Possibilities of cluster production of equipment for renewable energy sources in BiH, Mostar First International Scientific Conference on Engineering 'MAT 2010'; 2010, Mostar

[6] Zlomušica,, E.; Behmen, M; Ćatović, F.; Sarač, E. (2005). 'Wind farms Designing Principles Based on Maximum Energy and Investment Effect', 9th International Reserch/Expert Conference "Trends in the Development of Machinery and Associated Technology TMT 2005; 2005, Antalya

[7] Federal law about renewable energy sources (2013), Available from http://www.fmeri.gov.ba/zakon-o-obnovljivimizvorima-energije-i-kogeneracije.aspx Acessed: 2016-09-25

[8] Analysis for the Use of Wind Power for Electricity Generation in Bosnia and Herzegovina, "NIP, SA", 2006, Madrid 